\title{
THE INFLUENCE OF PROBIOTIC AND ENZYME MIXTURE CONTAINING PHYTASE ON GROWTH PERFORMANCE, CARCASS CHARACTERISTICS, MEAT QUALITY AND PLASMA BIOCHEMICAL CONSTITUENTS OF BROILER CHICKS FED DIFFERENT PLANT PROTEIN SOURCES Aggoor, F. A. M.; F. S. A. Ismail and E. A. Shakmak Poultry Production Department, Faculty of Agriculture, Mansouria University, Egypt.
}

\begin{abstract}
The influence of different dietary protein sources and two types of pro-nutrients e.g. enzyme mixture containing phytase and probiotics on growth performance, carcass characteristics, meat quality and plasma biochemical constituents of broiler chicks was studied herein as means of improving the utilization of diets containing different plant protein sources and decreasing feed cost. A complete randomized straight run experimental design including 10 dietary treatments was conducted. A basal control corn-soybean meal diet containing 22 and $20 \%$ CP in the starting and growing-finishing periods, respectively was formulated. Sunflower meal (SFM) and rocket (Eruca sativa) meal $(\mathrm{RM})$ individually or as a mixture of $(1: 1 ; \mathrm{Wt}:: \mathrm{Wt})$ replaced $25 \%$ of soybean meal protein. Thus, there were four main experimental diets. Moreover, the diets containing SFM and/or RM was either supplemented or not with enzyme mixture containing phytase (Natuzyme) or probiotics (Nutri-Bio Plus). Thus, there were 10 experimental treatments, Each diet was fed to 24 one d-old unsexed broiler chicks divided equally among four replicates of 6 chicks each housed in a battery $(30 \times 35 \times 40 \mathrm{~cm})$. At the end of the experiment (49 d of age), 3 chicks of each treatment were slaughtered to determine carcass characteristics and meat quality traits. Furthermore, four blood samples per treatment were collected to determine some biochemical constituents. Also, a digestibility trail and an economic efficiency study were carried out.

Although, substituting $25 \%$ of soybean meal protein by SMF and/or RM had no adverse effect on growth or feed conversion ratio (FCR) it improved protein conversion ratio (PCR) and economic efficiency of broiler chicks. Furthermore, Natuzyme and probiotics supplementation significantly improved growth, FCR, PCR and the economic efficiency, with the effect of probiotics was more efficient. Feed intake was significantly decreased due to inclusion of SFM and/or RM and further decreased by enzymes and probiotic supplementation, however, the effect of probiotics was stronger than enzymes. Enzyme supplementation improved significantly digestibility of dry matter of diet containing a mixture of SFM and RM. Sunflower meal and/or RM had no effect on dressing percentage, front and hind parts, meat quality and plasma total protein, globulin and albumin/globulin ratio, total lipids, cholesterol, inorganic phosphorous (iP), Ca and AST and ALT enzymes.

In conclusion, SFM and/or RM could be included in broiler diets to replace $25 \%$ of soybean meal protein without adverse effects on growth performance and economic efficiency. Furthermore, enzyme mixture and probiotics supplementation resulted in improved growth performance and economic efficiency. Whereas, probiotic supplemented-diet containing a mixture of SFM and RM resulted in the best productive performance and economic efficiency.
\end{abstract}

Keywords: Broilers, protein level, enzymes, probiotics, growth, meat quality. 


\section{INTRODUCTION}

Recently, protein nutrition represented a major challenge to poultry production especially in the region where protein rich feedstuffs are limited. The practical poultry feeding experienced to use soybean meal as a mean plant protein supplement since the discovery of cow mad disease (BSE) in the last decade (Attia et al., 2003; El-Deek et al., 2003). Formulating poultry diets based on corn-soybean meal has increased soybean meal demands and accordingly raised feeding cost. One of the possible approaches to reduce the feed cost for poultry is the use of alternative locally available protein sources. Diets containing soybean meal as a sole protein source may be deficient in methionine unless correctly formulated with other protein or synthetic amino acids (McNaughton and Deaton, 1981). Sunflower meal and rocket meal are by-products of sunflower oil and rocket oil extraction respectively, are available in the Egyptian market for use in animal feed and would be important when soybean meal is in shortage (Michel and Sunde 1985; Attia et al., 2003; El-Deek et al., 2003). Alib et al. (1988), Attia et al. (2003) and El-Deek et al. (2003) reported that sunflower meal containing 24.4-29\% CP, 16.3-18.3\% NFE, 14.6-15.8\% CF and 2.9-3.3\% ash. They added that the maximum amount of sunflower meal that could include in broiler diets appeared to be $15.0 \%$ in all mash diets and $30.0 \%$ in pelleted diets. Higher levels may adversely affect performance, however it could completely replace the supplemental protein if sufficient supplemental lysine is added (Deaton et al., 1979; McNaughton and Deaton 1981). They concluded in accordance with the results reported by Waldroup et al. (1970), Rad and Keshavarz (1976) and Zatari and Sell (1990a) that sunflower meal could replace $50.0 \%$ of soybean meal or included between $10.0-15.0 \%$ in the diet. Although, El-Sherif et al. (1995) reported that growth and feed-to-gain ratio of broilers fed diet containing $15.0 \%$ dehulled sunflower meal were poorer than those of the soybean meal-control ones. Rocket meal is expected to increase in the local market due to its use as a medical plant.

On the other hand, research work with rocket meal is limited. Osman et al. (2004), Fagbenro (2004) and El-Shafei et al. (2007) found that rocket meal contains $30-20-36.03 \%$ CP; $5.65-7.64 \%$ EE, $7.69-10.20 \%$ CF,8.36-11.83\% ash and $36.81-38.22 \%$ NFE and could be used up to $10 \%$ in broiler diets, $20 \%$ of dietary protein in catfish and $15 \%$ in the diet for growing Japanese quail, respectively. Rocket meal had $0.34-0.35 \%$ methionine, methionine and cystine $0.42-.54 \%, 1.18-1.93 \%$ lysine, $0.98 \%$ threonine, $2.08 \%$ arginine and $1.27 \%$ valine (Osman et al., 2004; El-Shafei et al., 2007), and $0.45 \% \mathrm{Ca}$ and $0.60 \%$ total phosphorus.

Fiber content of sunflower meal may restrict its use to $8.0 \%$ in broilergrowing diets and $16.0 \%$ in broiler-finishing diets, but not restrict its use in layer diets (McNaughton and Deaton, 1981). Sunflower meal NSP contains $11.5 \%$ uronic acid (pectin), $13.0 \%$ xylose and $7.7 \%$ arabinose (Carré and Brillouet, 1986). Sunflower meal NSP was higher than that of soybean meal, due to increased concentrations of cellulose and xylose in the insoluble NSP and uronic acids in soluble NSP (Irish and Balnave, 1993). It was concluded 
that formulating poultry diets required specific attention to the nutrient-diluting effects of sunflower meal fiber or NSP (Carré and Brillouet 1986; Francesh et al., 1995) and the limiting amino acids lysine, arginine and threonine (Cuca et al., 1973; Tsvetanov et al., 1984).

The use of prebiotics and probiotics in poultry nutrition are widely emphasis as a mean of improving animal health, control pathogens and increased nutrient utilization through keeping healthy gut ecology (Makeld, 1991; Patterson and Burkholder, 2003; FAO, 2006, Piray et al., 2007). Enzyme mixture or phytase may be a practical mean to improve performance and permit utilization of higher levels of agro-industrial by-product in monogastric animal nutrition (Attia et al., 2001). Multienzymes containing $\beta$ glucanase, $\alpha$-amylase, cellulase, pectinase, xylanase, hemicellulase without or with protease and phytase could improve feed utilization and overcame the antinutritional factors of feedstuffs, improve gut health and immune response (Jeroch et al., 1995; Saleh et al., 2003; Yonemochi et al., 2003; Gahzalah et al., 2005; Meng et al., 2005; Choct, 2006). Thus, the effect of probiotic and enzyme mixture containing phytase on growth performance, carcass characteristics, meat quality and biochemical constituents of blood plasma of broiler chicks fed diets containing a mixture of different plant protein sources was investigated herein as means of improving nutrinet utilization and reducing feeding costs of broiler chicks.

\section{MATERIALS AND METHODS}

\section{Experimental design, birds and diets}

A complete randomized straight run design including 10 dietary treatments was conducted. A basal control corn-soybean meal and corn gluten meal diet containing 22 and $20 \% \mathrm{CP}$ in the starting and growing-finishing periods, respectively was formulated. Sunflower meal and rocket (Eruca sativa) meal individually or as a mixture of (1:1) replaced $25 \%$ of soybean meal protein. Thus, there were four main experimental diets in the starting (Table 1), and growing-finishing periods (Table 2). Moreover, the diets containing sunflower meal and/or rocket meal was fed either without or with enzyme mixture containing phytase (Natuzyme ${ }^{1}$ ) and probiotics (Nutri-Bio Plus ${ }^{2}$ ). Thus, there were 10 experimental treatments, each diet was fed to 24 one d-old unsexed broiler chicks divided equally among four replicates of 6 chicks each housed in a battery $(45 \times 35 \times 40 \mathrm{~cm})$. The chicks ( $n=240$ of Ross strain) were wing banded and distributed randomly among the experimental diets at day of hatch with keeping similar initial live body weight among replicates and treatments. The diets were formulated based on tables of feedstuffs, and met

\footnotetext{
${ }^{1}$ Natuzyme $^{\circledR}$, (www. Alboraqmisr.com, $33511 \quad$ Mansoura-Egypt, E-mail info@alboraqmisr.com)) was added at $1 \mathrm{~g} / \mathrm{kg}$. It is multifunctional feed enzyme mixture containing cellusase, xylanase, $\beta$-glucanase, $\alpha$-amylase, protease, pectinase, and phytase. It also contains hemicellulases, amyloglycosidases and pentosanases activities.

${ }^{2}$ Nutri-Bio Plus ${ }^{\circledR}$, is a grower promoter of AMECO-BIOS\& CO, 339 W. Lemon Ave, Arcadia, CA 91007, USA, Email:amecobies@gmail.com). It's recommended dose of use is 200$500 \mathrm{~g} /$ ton feed. It is composed of Bacillus subtillis fermentation extract $130 \mathrm{~g}$, Brewers yeast extract $170 \mathrm{~g}$, lactic acid $20 \mathrm{~g}$, citric acid $10 \mathrm{~g}$, calcium propionate $100 \mathrm{~g}$, sodium aluminosilicate $550 \mathrm{~g}$ and DL-methionine $20 \mathrm{~g}$.
} 
Aggoor, F. A. M. et al.

nutrient requirements of broiler chicks (NRC, 1994). Feed and water were offered ad libitum throughout the experiment. Chicks were kept under similar managerial and hygienic conditions and illuminated with $23 \mathrm{~h}$ light/d up to 49 d of age.

Table (1).Composition and calculated analyses of the starting experimental diets

\begin{tabular}{|c|c|c|c|c|}
\hline \multirow[t]{2}{*}{ Ingredients, $\%$} & \multicolumn{4}{|c|}{ Starting diets } \\
\hline & Control & $25 \%$ SFM & $25 \%$ RSM & 25\%SFM+RSM \\
\hline Yellow corn & 60.00 & 55.50 & 60.00 & 57.50 \\
\hline Soybean meal (44\% CP) & 19.00 & 10.61 & 10.00 & 10.48 \\
\hline Corn Gluten meal (\%) & 13.78 & 11.48 & 11.30 & 11.29 \\
\hline Sunflower meal & 0.00 & 14.48 & 0.00 & 7.24 \\
\hline Rocket meal & 0.00 & 0.00 & 13.45 & 6.73 \\
\hline Commercial oil blend & 2.63 & 3.82 & 2.39 & 3.16 \\
\hline Dicalcium phosphate & 1.77 & 1.73 & 1.47 & 1.60 \\
\hline Lime stone & 1.45 & 1.35 & 0.25 & 0.87 \\
\hline Vit+Min mixture $^{1}$ & 0.30 & 0.30 & 0.30 & 0.30 \\
\hline $\mathrm{NaCl}$ & 0.30 & 0.30 & 0.30 & 0.30 \\
\hline Dl-methionine & 0.02 & 0.03 & 0.12 & 0.08 \\
\hline L-lysine & 0.29 & 0.42 & 0.42 & 0.44 \\
\hline Wash building sand & 0.46 & 0.00 & 0.00 & 0.00 \\
\hline Total & 100.0 & 100.0 & 100.0 & 100.0 \\
\hline \multicolumn{5}{|c|}{ Calculated values } \\
\hline ME-kcal $/ \mathrm{kg}$ diet & 3192 & 3213 & 3197 & 3203 \\
\hline Crude protein & 22.1 & 22.2 & 21.7 & 22.0 \\
\hline Methionine \% & 0.45 & 0.44 & 0.50 & 0.48 \\
\hline Methionine plus cystine $\%$ & 0.84 & 0.81 & 0.82 & 0.83 \\
\hline Lysine, \% & 1.03 & 1.01 & 1.02 & 1.03 \\
\hline $\mathrm{Ca}, \%$ & 1.00 & 0.96 & 0.95 & 0.98 \\
\hline Available P, \% & 0.45 & 0.43 & 0.43 & 0.43 \\
\hline \multicolumn{5}{|c|}{ Determined values } \\
\hline Dry matter,\% & 89.51 & 89.38 & 89.74 & 89.18 \\
\hline Crude protein & 21.73 & 21.81 & 21.77 & 21.86 \\
\hline Ether extract, \% & 5.21 & 6.18 & 5.08 & 6.01 \\
\hline Crude fibre, $\%$ & 2.43 & 3.11 & 2.69 & 2.86 \\
\hline Crude ash, \% & 9.81 & 9.67 & 9.58 & 9.74 \\
\hline
\end{tabular}

1 Vitamins and minerals mixture provide per kilogram of diet vitamin A (as all-transretinyl acetate); $12000 \mathrm{IU}$; vitamin $\mathrm{E}$ (all rac- $\alpha$-tocopheryl acetate); $10 \mathrm{IU}$; $\mathbf{k}_{3} 3 \mathrm{mg}$; Vit. $\mathrm{D}_{3}$, $2200 \mathrm{ICU}$; riboflavin, $10 \mathrm{mg}$; Ca pantothenate, $10 \mathrm{mg}$; niacin, $20 \mathrm{mg}$; choline chloride, $500 \mathrm{mg}$; vitamin $B_{12}, 10 \mu \mathrm{g}$; vitamin $B_{6}, 1.5 \mathrm{mg}$; thiamine (as thiamine mononitrate); 2.2 $\mathrm{mg}$; folic acid, $1 \mathrm{mg}$; D-biotin, $50 \mu \mathrm{g}$. Trace mineral (milligrams per kilogram of diet) $\mathrm{Mn}$, 55; Zn, 50; Fe, 30;Cu, 10; Se, 0.1 and Ethoxyquin 3mg.

Birds were weighed $(\mathrm{g})$ individually at 14,28 and $49 \mathrm{~d}$ of age, and feed intake was recorded by replicate at the same time and FCR ratio was calculated on a replicate basis. Protein conversion ratio was calculated by dividing protein intake by body weight gain. Coefficient of apparent digestibility of nutrients of the total gut was calculated according to Attia et al. (2007) using three replicates of one male each/ treatment. 
At 49 wk of age, 3 chicks were taken randomly from each treatment, and slaughtered; the remaining carcass after bleeding, was plucked and eviscerated then weighed (dressed weight) and divided into chest and hind parts and weighed. Liver, gizzard, heart and spleen were separated and individually weighed. The carcass parts were expressed as relative to live body weight. A sample of breast meat and thigh meat $(1: 1, \mathrm{Wt}: \mathrm{Wt})$ and the experimental diets were chemically analyzed for dry matter (DM), crude protein (CP), ether extract (EE) and crude ash (CA) according to AOAC (1990). Meat tenderness and water holding capacity (WHC) were measured according to the method of Volvoinskaia and Kelman (1962). Color intensity of meat and drip were determined according to the method of Husani et al. (1950), whereas $\mathrm{pH}$ value was measured by a $\mathrm{pH}$ meter as described by Aitken et al. (1962)

Table (2).Composition and calculated analyses of the growing-finishing experimental diets

\begin{tabular}{|c|c|c|c|c|}
\hline \multirow[t]{2}{*}{ Ingredients, $\%$} & \multicolumn{4}{|c|}{ Growing-finishing diets } \\
\hline & Control & $25 \%$ SFM & $25 \% R S M$ & 25\%SFM+RSM \\
\hline Yellow corn & 63.90 & 60.00 & 60.00 & 60.00 \\
\hline Soybean meal (44\% CP) & 18.99 & 9.50 & 10.00 & 9.83 \\
\hline Corn Gluten meal (\%) & 10.03 & 9.00 & 9.30 & 9.00 \\
\hline Sunflower meal & 0.00 & 13.16 & 0.00 & 6.58 \\
\hline Rocket meal & 0.00 & 0.00 & 12.23 & 6.11 \\
\hline Commercial oil blend & 2.82 & 3.725 & 3.59 & 3.69 \\
\hline Dicalcium phosphate & 1.80 & 1.76 & 1.53 & 1.65 \\
\hline Lime stone & 1.20 & 1.215 & 0.24 & 0.72 \\
\hline Vit+Min mixture $^{1}$ & 0.30 & 0.30 & 0.30 & 0.30 \\
\hline $\mathrm{NaCl}$ & 0.30 & 0.30 & 0.30 & 0.30 \\
\hline Dl-methionine & 0.05 & 0.08 & 0.14 & 0.11 \\
\hline L-lysine & 0.30 & 0.48 & 0.44 & 0.46 \\
\hline Wash building sand & 0.31 & 0.48 & 1.93 & 1.25 \\
\hline Total & 100.0 & 100.0 & 100.0 & 100.0 \\
\hline \multicolumn{5}{|c|}{ Calculated values } \\
\hline ME-kcal/kg diet & 3201 & 3212 & 3201 & 3206 \\
\hline Crude protein & 20.21 & 20.25 & 20.11 & 20.12 \\
\hline Methionine \% & 0.43 & 0.44 & 0.48 & 0.46 \\
\hline Methionine plus cystine \% & 0.78 & 0.78 & 0.78 & 0.78 \\
\hline Lysine, \% & 1.00 & 1.00 & 1.00 & 1.00 \\
\hline $\mathrm{Ca}, \%$ & 0.91 & 0.91 & 0.91 & 0.95 \\
\hline Available P, \% & 0.43 & 0.44 & 0.48 & 0.46 \\
\hline \multicolumn{5}{|c|}{ Determined values } \\
\hline Dry matter,\% & 89.71 & 89.50 & 89.39 & 89.65 \\
\hline Crude protein & 19.83 & 19.76 & 19.71 & 19.84 \\
\hline Ether extract, \% & 5.25 & 6.31 & 5.10 & 6.18 \\
\hline Crude fibre, $\%$ & 2.41 & 2.98 & 2.69 & 2.80 \\
\hline Crude ash, \% & 9.71 & 9.83 & 10.51 & 10.46 \\
\hline
\end{tabular}

${ }^{1}$ As shown in Table 1.

At $49 \mathrm{~d}$ of age, four blood samples of each treatment were collected in heparinzed tubes. Plasma was separated by centrifugation at $3000 \mathrm{rpm}$ for 15 minutes and stored at $-20^{\circ} \mathrm{C}$ until analysis. Concentrations of total protein (Henry et al., 1974), albumin (Doumas et al., 1977), total lipids (Chabrol and 
Charonnat, 1973), total cholesterol (Watson, 1960), alanine aminotransferase (ALT) and aspartate aminotransferase (AST) (Retiman and Frankel, 1957), Ca (Sendroy, 1944), and inorganic P (Gomorri, 1942) were determined by colorimetric method using commercial available kits. Globulin was calculated by differences between total protein and albumin. Furthermore, economic evaluation for all experimental diets was done as described by Zeweil (1996).

\section{Statistical Analysis}

Data were analyzed using the GLM procedure of Statistical Analysis Software (SAS) version 6.11 (SAS ${ }^{\circledR}$ Institute, 1990, Cary, NC, USA) using two-way factorial design. Mean difference at $P \leq 0.05$ was tested using Duncan New multiple range test (Duncan, 1955).

\section{RESULTS AND DISCUSSION}

Growth performance, protein conversion ratio and economic efficiency

Growth of broiler chicks as affected by different plant protein sources without or with pro-nutrients is presented in Table (3). Data indicate that growth of chicks was significantly affected by dietary treatments at 14, 28 and $49 \mathrm{~d}$ of age and for the whole experimental period. The present results indicate that inclusion of $25 \%$ of SFM and/or RM had no harmful effect on growth of broiler chicks. However, a combination of SFM and RM significantly increased growth by $\sim 2.5 \%$ of broilers at only $14 \mathrm{~d}$ of age compared to the control group when unsupplemented diets were compared. The superiority of diet containing combination of plant protein sources indicated a complementary effect which might have increased availability of amino acids and/or eliminate the anti-nutritional substance or amino acid imbalance (Irish and Balnave, 1993 and Attia et al., 1998; 2003). Attia et al. (1998; 2003), Senkoyla and Dale (1999) and Daghir (2008) concluded that SFM may be included in poultry diets up to $15 \%$ without adverse effect on growth when supplemented with adequate amino acids. On the other hand, results reported by Osman et al. (2004) reported that higher than $10 \%$ of RM in broiler diets adversely affect performance. Also, El-Shafei et al. (2007) indicated that RM could be used up to $15 \%$ in the diet for growing Japanese quail without adverse effect on growth performance. Whereas, Fagbenro (2004) found that RM at $20 \%$ of total dietary protein did not affect growth of African catfish.

Enzymes and probiotics supplementations to SFM and RM diets significantly increased growth compared to its negative control; however, probiotics was more efficient with each protein source. Difference between enzymes and probiotics was significant up to $28 \mathrm{~d}$ of age, and diminished in SFM and RM thereafter. However, probiotic had a superior significant positive effect on diet containing a combination of SFM and RM than enzyme supplemented-group. Results indicate that the effect of pro-nutrients depends on dietary composition and age of chicks, as probiotics had strong effect on SFM containing diets and up to $28 \mathrm{~d}$ of age. These results are in agreement with those reported by Soliman et al. (1996) and Attia et al. (1998; 2003) who reported that enzyme addition to duck and broiler diets containing 
different levels of sunflower meal had some beneficial effect on growth and feed utilization especially at the high sunflower meal level. However, Kocher et al. (2000) indicated that commercial enzyme products had no appreciated effect on sunflower meal containing-diet. On the other hand, the positive effect of probiotic cocktail could be explained by the effect of probiotics on gut health and elimination of the harmful substances including the indetectable level of mycotoxicns due to its contents of Bacillus subtillis fermentation extract, Brewers yeast extract, lactic acid, citric acid, calcium propionate, sodium aluminosilicate and DL-methionine. These results are in agreement with those reported by Makled (1991), Patterson and Burkholder, 2003; Sun et al. (2005), FAO (2006) and Piray et al. (2007).

For the whole experimental period, inclusion of SFM and/or RM in broiler diets to replace $25 \%$ of soybean meal did not significantly affect growth, indicating lack of negative effects. On the other hand, both Natuzyme and probiotics significantly improved growth compared to their negative control in each diet, however, difference was only significantly in favor of probiotics in the diet containing a combination of SFM and RM. It is clear that any diet supplemented with Natuzyme or probiotics had better growth than the positive control, showing the beneficial of pro-nutrients for improving nutrient utilization. It was found that the highest growth was from group fed a mixture of SFM and RM supplemented with probiotics, while the lowest growth was from unsupplemented group fed RM, with as significant difference between these groups.

There were no dead birds during the experimental period. Similarly, Attia et al. (1998; 2003), Suresh et al. (2000), Osman (2004), Fagbenro (2004) and El-Shafei et al. (2007) found that SFM and RM had no adverse effect on morality rate of birds.

Feed intake of broiler chicks as affected by different plant protein sources without or with pro-nutrients is presented in Table (3). Data indicate that feed intake of chicks was significantly affected by dietary treatments during 1-14, $15-28$ and $29-49$ as well as during 1-49 d of age. Results reveal that inclusion of $25 \%$ of SFM and/or RM significantly decreased feed intake of broilers during all experimental period compared to the control. The results indicate that group fed diet containing a mixture of SFM and RM consumed lower feed intake than those fed RM alone during 1-14, 15-28 and 1-49 $\mathrm{d}$ of age. Whereas, difference was insignificant between groups fed RM or SFM and those fed a mixture of SFM and RM during 29-49 d of age. These results indicate that a combination of SFM and RM had stronger negative effect on feed intake compared to any of them. For the whole experimental period, the decrease in feed intake due to inclusion of SFM and/or RM was 1.8, 1.2 and $2.2 \%$ respectively. These results are in agreement with those reported by Attia et al. (1998; 2003) with SFM fed to Peckin ducks and broiler chicks. No adverse effect of RM on feed intake of broiler chicks was also shown by Osman et al. (2004), also El-Shafei et al. (2007) found no effect of RM on feed intake of Japanese quail.

Enzymes and probiotics supplementation to different plant sources containing diets had further significant negative effect on feed intake compared to their negative control. 
Aggoor, F. A. M. et al.

3

2508 
Furthermore, probiotic had stronger negative effect than enzymes supplementation in each diet and this depends on dietary composition and age of chicks. For the whole experimental period, enzymes and probiotics decreased feed intake by 2.7 and $3.6 \%$ respectively, of SFM diet compared to their negative control. The corresponding value for RM diet was 2.2 and $3.6 \%$ respectively. Meanwhile, the corresponding value for diet containing a mixture of SFM and RM was 3.4 and $5.7 \%$ respectively. This indicates that enzymes and probiotics had stronger effect on diet containing a mixture of SFM and RM than diet containing SFM or RM only. The effect of enzymes and probiotics on feed intake is related to dietary composition and age of chicks (Jeroch et al., 1995; Attia et al., 2001). Kidd et al. (2001) reported that enzymes did not affect feed intake of broiler chicks. On the other hand, Piray et al. (2007) observed that prebiotic increased feed intake compared to the unsupplemented control group.

Feed conversion ratio, PCR and economic efficiency of broiler chicks as affected by different plant protein sources without or with pro-nutrients are presented in Table (4). Data indicate that FCR of chicks was significantly influenced by inclusion of SFM and/or RM during 1-14, 15-28 and 29-49 d of age and for the whole experimental period, too. The present results indicate that inclusion of $25 \%$ of SFM and/or RM had no adverse impact on FCR of broiler chicks. However, a combination of SFM and RM significantly improved FCR by $\sim 6.2 \%$ of broilers during $1-14 \mathrm{~d}$ of age compared the control group when unsupplemented sources were compared. This may be due to the $2.5 \%$ increase in growth and $2.1 \%$ decrease in feed intake. Also, a combination of SFM and RM significantly improved FCR compared to the SFM or RM during the same period. During 15-28 and 29-49 d of age, there were no significant differences in FCR among the unsupplemented diets containing different plant protein sources. For the whole experimental period, FCR was numerically improved due to inclusion of SFM and RM compared to the control group. Meanwhile, inclusion of a mixture of SFM and RM resulted in significantly better (2.9\%) FCR compared to the control group. Attia et al. (1998; 2003) Senkoyla and Dale (1999) and Daghir (2008) concluded that SFM may be included in poultry diets up to $15 \%$ without adverse effect on FCR when supplemented with adequate amino axids. On the other hand, results observed by Osman et al. (2004) with broiler chicks, El-Shafei et al. (2007) with Japanese quail and Fagbenro (2004) with African catfish indicated that up to $10-15 \%$ of $\mathrm{RM}$ in broiler and Japanese quail diets and $20 \%$ of total dietary protein did not adversely affect FCR. On the other hand, El-Sherif et al. (1995) reported that FCR of broilers fed diet containing $15.0 \%$ dehulled sunflower meal were poorer than those of the soybean mealcontrol ones.

Protein conversion ratio was significantly improved due to inclusion of SFM and /or RM in broiler diets, with the effect of RM was significantly better than SFM and the mixture was better than both. These results provided further evidences for the improvement in amino acids balance due to inclusion of different plant protein sources. Attia et al. $(1998 ; 2003)$ reported similar results. 
Aggoor, F. A. M. et al.

4 
Economic efficiency was significantly increased due to inclusion of SFM and /or RM in broiler diets, with the effect of RM was similar to that of RM and the mixture was better than both.

Enzymes and probiotics supplementations to SFM and/or RM containing diets significantly improved FCR compared to its negative control; however, probiotics was significantly more efficient within each protein source. Difference between enzymes and probiotics was significant up to 28 $\mathrm{d}$ of age, and diminished in SFM and RM thereafter, while remains significant in the diet containing the mixture of two tested plant protein sources with superiority of probiotics.

For the whole experimental period, both Natuzyme and probiotics significantly improved FCR and PCR compared to their negative control in each tested diet. Furthermore, the difference was significant in favor of probiotics in each tested ingredient. For example, enzymes and probiotics improved FCR of SFM diet by 6.4 and $9.3 \%$, respectively. The corresponding values for RM diet were 5.0 and $8.0 \%$, respectively. For diet containing the mixture, the improvements due to enzymes and probiotics were 7.0 and $11.6 \%$, respectively. It was found that Natuzyme or probiotics supplemented-diet had better FCR and PCR than the positive control, showing the beneficial of pro-nutrients for improving nutrient utilization. It was found that the best FCR and PCR was from group fed a mixture of SFM and RM supplemented with probiotics, while the poorest FCR and PCR was from unsupplemented control group fed corn-SBM and corn gluten meal diet, with a significant difference (14.2 and $9.3 \%$, respectively) between these groups. Results reveal that the effect of pro-nutrients depends on dietary composition and age of chicks, as enzymes and probiotics had strong effect on SFM containing diets. This indicates that sunflower meal was targeted by enzymes mixture and probiotic compared to RM diet. It should be mentioned, however, that the effect of enzymes or probiotics could not totally attributed to its effect on SFM and/or RM but also to the other components of the experimental diets such as corn, soybean meal and corn gluten meal (Attia et al., 2003; 2007; 2008; Saleh et al., 2003; Choct, 2006)

These results are in agreement with those reported by Soliman et al. (1996) and Attia et al. (1998; 2003) who reported that enzyme addition to duck and broiler diets containing different levels of sunflower meal had some beneficial effect on feed utilization especially at the high sunflower meal level. However, Kocher et al. (2000) indicated that commercial enzyme products had no appreciated effect on sunflower meal containing-diet. On the other hand, the positive effect of probiotic cocktail are in agreement with those reported by Makled (1991), Patterson and Burkholder, (2003), Sun et al. (2005), FAO (2006) and Piray et al. (2007).

Economic efficiency was significantly improved due to supplementation of enzymes mixture and probiotics, and the effect of probiotics was significantly stronger in each diet than the effect of enzyme mixture. The results indicate that the best economic efficiency was from probiotic supplemented-diet containing a mixture of SFM and RM, while the poorest was from the positive control. 
Apparent digestibility of nutrients and ash retention:

Results for the effect of dietary composition and pro-nutrients supplementation on apparent digestibility of the experimental diets are shown in Table (4). Results demonstrate that SFM and/or RM and enzyme supplementation had no negative effects on apparent digestibility of nutrient and ash retention. The results indicate that enzyme supplementation to diet containing $25 \%$ of mixture of SFM and RM increased digestibility of dry matter by 4.7 and $4.2 \%$ compared to the positive and the negative control. This group also, had better digestibility of DM than the unsupplemented SFM or RM diet. There was no significant difference between enzymes supplemented diets or probiotics supplemented ones when comparison was made within or over different tested sources. The increase in dry matter digestibility could enhance ME value of the diet, and increase ME availability for growth (Jeroch et al., 1995; Cowan et al., 1996; Zanella et al.1999, Ghazalah et al., 2005 and Attia et al. 2007 and 2008). However, Rebolé et al. (1999) reported that enzyme addition to broiler diets containing $15 \%$ sunflower meal did not significantly improved digestibility of protein/amino acid, fat/fatty acids and ME.

Carcass characteristics and body organs:

Results for the effect of dietary composition and pro-nutrients supplementation on carcass characteristics and body organs are shown in Table (5). Results indicate that SFM and/or RM and enzyme supplementation had no significant effects on percentage dressing, inedible parts, front and hind parts and heart. Also Osman et al. (2004) and El-Shafei et al. (2007) reported that RM up to $15 \%$ in broilers and Japanese quail diets had no adverse effects on carcass characteristics and body organs.

SFM caused spleen hypertrophy compared to the other unsupplemented diets, while RM significantly decreased liver percentage compared to the other unsupplemented diets. The increase in spleen percentage due to inclusion of sunflower indicated the negative effect of sunflower NSP on gut ecology. Carré and Brillouet (1986) indicated that NSP of sunflower meal contain $11.50 \%$ uronic acid (pectin), $13.0 \%$ xylose and $7.7 \%$ arabinose. The fermentation of these substances may encourage the growth of pathogenic organisms (Attia et al., 1998; 2003) due to lack digestive matching enzymes. This was confirmed by the positive effect of probiotic on spleen, thus complete recovery was observed compared to the positive control.

It was found that probiotic supplementation decreased liver percentage of SFM diet compared to its negative control and the positive control, too. Supplementation with either enzymes or probiotic to $25 \%$ RM diet significantly decreased gizzard percentage compared to its negative control, and the effect of probiotic was more efficient, thus difference from the positive control was diminished. Difference in giblets percentage due to different unsupplemented protein sources was insignificant; however, proboitic supplementation to SFM and/or RM diets significantly decreased giblets percentage compared to its negative control. Enzyme supplementation exhibited similar effect on only the diet containing a mixture of SFM and RM. These results are similar to those reported by Piray et al. (2007) and Attia et al. (1998; 2001; $2007 ; 2008)$. These authors reported that pro-nutrients e.g. enzymes and probiotics improved availability of nutrients and overcame the anti-nutritional substances. 
J. Agric. Sci. Mansoura Univ., 33 (4), April, 2008

2513 
Meat quality:

Data for chemical composition of meat e.g. percentage DM, CP, EE and ash and physical characteristics e.g. $\mathrm{pH}$, color, tenderness and WHC are shown in Table (5). Results reveal that different protein sources and/or pronutrients supplementations had no significant effect on chemical composition and consequently on physical characteristics of meat. These results are similar to those reported by Attia et al. (1998; 2003; 2008). These authors indicated that protein sources and enzyme supplementation had no effect on chemical composition and physical characteristics of meat.

\section{Biochemical constituents of blood plasma}

Results for biochemical composition of blood plasma and plasma $\mathrm{Ca}$ and iP are shown in Table (6). Results reveal that SFM and/or RM and pronutrient supplementation had no effect on plasma total protein, globulin and albumin/globulin ratio, total lipids, cholesterol, inorganic phosphorus, $\mathrm{Ca}$ and AST and ALT enzymes. These results are similar to those reported by ElDeek et al. (2003) with SFM, Osman et al. (2004) found no negative effect of RM up to $15 \%$ in broiler blood hemoglobin, plasma total protein, albumin, globulin and albumin to globulin ratio, while more than 5\% significantly decreased plasma total lipids, cholesterol, GOT and GPT. Also, El-Shafei et al. (2007) found that RM had no adverse effects on blood contents of Japanese quail.

Results show that plasma albumin was significantly decreased due to inclusion of SFM and RM mixture compared to only the positive control. However, enzyme and probiotic supplementation restored plasma albumin to the level of the positive control. Also, enzyme supplementation to the diet containing a mixture of SFM and RM increased plasma Ca compared to the unsupplemented diet containing SFM and/or RM and the positive control, too. This increase in plasma Ca due to enzyme supplementation may be due to phytase containing of the enzyme mixture which is well known for improving mineral availability (Kies et al., 2001; Choct, 2006; Panda et al., 2007 and Selle et al., 2006). The results indicated that probiotics had no significant effect on plasma Ca level, however, differences from enzyme supplemented groups were not significant.

The present results indicate that inclusion of SFM and/or RM did not affect liver functions, furthermore, supplementation of enzymes mixture and probiotics had nor effect, too. These results are similar to those reported by Attia et al. (2001; 1998; 2003).

In conclusion, SFM and/or RM could be included in broiler diets to replace $25 \%$ of soybean meal protein without adverse effect on growth performance and economic efficiency; furthermore enzyme mixture and probiotics supplementation resulted in improved growth performance and economic efficiency. Whereas, probiotic supplemented-diet containing a mixture of SFM and RM resulted in the best productive performance and economic efficiency. 
J. Agric. Sci. Mansoura Univ., 33 (4), April, 2008

6

2515 


\section{REFERENCES}

Aitken A, J. C. Casey, I.F. Penny and C. A.Volys (1962). Effect of drying temperature in the accelerated freezes drying of pork. Journal Science Food Agriculture, 13: 439.

Alib, K., C.W. Carlson and D.U. Ahn (1988). The value of sunflower seed oil meal as a protein supplement for laying hens. Can. J. Anim. Sci., 39:45-49.

Association of Official Analytical Chemists AOAC (1990). Official methods of analysis. $15^{\text {th }}$ edition, Arlington, Virginia, USA.

Attia Y.A., S. A. Abd El-Rahman and E. M. A.Qota (2001). Effects of microbial phytase without or with cell-wall splitting enzymes on the performance of broilers fed marginal levels of dietary protein and metaboilzable energy. Egypt Poultry Science, 21: 521-547.

Attia,Y.A.M. A.Al-Harthi and A.A.El-Deek (2003).Nutritive value of undehulled sunflower meal as affected by multienzymes supplementation to broiler diets._Archiv Für Geflügelkunde 67(3):97-106.

Attia, Y. A., Barbara M. Böhmer, Dora A. Roth-Maier (2006). Responses of broiler chicks raised under constant relatively high ambient temperature to enzymes, amino acid supplementations, or diet density. Archiv Für Geflügelkunde, 70 (2): 80-91.

Attia, Y. A., A. A. El-Deek and Mona, Osman (1998). Evaluation of sunflower meal as a feedstuff in diets for ducks. Archiv Fur Geflugelkunde, 62 (6):273-282.

Attia, Y.A., A. E. Tag El-Din, H. S. Zeweil, A. S. Hussein and M. A. Arafat (2008). The effect of supplementation of enzyme on laying and reproductive performance in Japanese Quail hens fed nigella seed meal. J. of Poult. Sci. 45:110-115.

Attia, Y.A., E. M. A.Qota, A. E. Abd El-Hamid and T. A. Sadaka (2007). The response of slow growing meat type chicks to the supplementations of different methionine levels and/or two types of enzymes. Emir J. Food Agric. 19 (2):48-63.

Attia, Y. A., Barbara M. Böhmer and Dora A. Roth-Maier (2006). Responses of broiler chicks raised under constant relatively high ambient temperature to enzymes, amino acid supplementations, or diet density. Archiv Für Geflügelkunde, 70:80-91.

Carré, B. and M. Brillouet (1986). Yield and composition of cell wall residues isolated from various feed-stuffs used for non-ruminant farm animals. J. Sci. Food and Agric., 37, 341-351.

Chabrol E and R. Charonnat (1973). Determination of total lipids. Press medical, 45: 1713-1720.

Choct, M. (2006). Enzymes for the feed industry: past, present and fututre. World's Poultry Science Jounral, 62: 5-15.

Cowan, W.D., A. Korsbak, T. Hastrup and P.B. Rasmussen (1996). Influence of added microbial enzymes on energy and protein availability of selected feed ingredients. Animal Feed Science Technology, 60:311319. 
Cuca, M.,E. Avila and E. Sosa, 1973: Threonine supplementation to sunflower diets for chicks. Poultry Sci. 52, 2016-2017.

Daghir, N. J. (2008). Poultry production in hot climates, $2^{\text {nd }}$ edn, CAB International

Deaton, J. W., J. L. McNaughton and D. Burdick (1979). High-fiber sunflower meal as a replacement for soybean meal in layer diets. Br. Poultry Sci., 20: 159-162.

Doumas, B.T., Watson, D. and H.G. Biggs (1977). Albumins standards and the measurement of blood albumin with bromocrisol green. Clinical Chemist Acta, 31: 87.

Duncan, D. B. (1955). The multiple range and F-test. Biometrics 11:1-42.

El-Deek, A. A., Y. A. Attia and Amal A. Soliman (2003). Productivity response of broiler breeder hens when fed practical or vegetable diets containing high levels of barley, sunflower meal or barley and sunflower meal without or with enzyme mixture supplementation 1-Barley. Egyptian Poultry Sci., 23:239-257.

El-Shafei, A. A., Abdel-Rhman, Abeer S., M. I. H. Amena, A. El-Sisi (2007). Effect of feeding variable rocket meal percentages on immune, biochemical and growth status of Japanese quail. Egypt. Poult. Sci. 27:663-688.

El Sherif, Kh., T. Gippert and G. Gerendai (1995). Effect of adding different levels of expeller sunflower seed meal in broiler diets. Pages 46-51 in: Proc. First Egyptian Hungarian Poultry Conf. Sep, 1994, Alexandria, Egypt.

Fagbenro, O. A. (2004). Soybean meal replacement by roquette (Eruca sativa Miller) seed meal as protein feedstuff in diets for African catfish, Clarias gariepinus (Burchell 1822),fingerlings . Aquaculture research 35:917-923

FAO (2006). Probiotics in food, health and nutritional properties and guidelines for evaluation, FAO, Food and nutrition Paper 85. World Health Organizations and Food and Agriculture Organization of the United Nations, Roma, 2006.

Francesh, Maria, Ana-Maria Perez-Vedrell, E. Esteve- Garcia and J. Brufau (1995). Enzyme supplementation of a barley and sunflower-based diet on laying hen performance. J. Appl. Poultry Res. 4, 32-40.

Ghalazah, A. A. A. H. Abd El-Gawad, M .S. Soliman and Amany W. Youssef (2005). Effect of enzyme preparation on performance of broilers fed corn-soybean meal based diet. Egypt Poult. Sci. 25:295-316.

Gomorri, G. (1942). Determination of inorganic phosphorus in plasma. J. Laboratory Clinical Meolical, 27: 955.

Henry, R., D. Cannon and J. Winkelman (1974). Clinical chemist principles and techniques, $2^{\text {nd }}$ Edn. Haper and Row.

Husani, S.A., F.B. Deatherage and L.E. Kunlkle (1950). Studies on meat.11: Observations on relation of biochemical factors to change in tenderness. Feed Technology, 4: 366-369.

Irish, G. G. and D. Balnave (1993). Non-starch polysaccharides and broiler performance on diets containing soybean meal as the sole protein concentrate. Australian J. of Agric. Res., 44: 1483-1499. 
Jeroch H., S. Danicke and J. Brufau (1995). The influence of enzyme preparations on the nutritional value of cereals for poultry: a review. Journal of Animal and Feed Science, 4: 263-285.

Kidd, M.T., j. w. Morgan, Jr. and C. J. Price (2001). Enzyme supplementation to corn and soybean meal diets for broilers. J. Appl. Poult. Res., 10:6570.

Kies A.K., K.H.F. Van Hemert and W.C. Sauer (2001). Effect of phytase on protein and amino acid digestibility and energy utilization. World's Poultry Science Journal, 57: 109-126.

Kocher, A., M. Choct, M.D. Porter and J. Broz (2000). The effects of enzyme addition to broiler diets containing high concentrations of canola or sunflower meal. Poult. Sci., 79:1767-1774.

Makled, M. N. (1991). The potentials of probiotics in poultry feeds- A review, pp. 54-71, In Proceedings of the $3^{\text {rd }}$ scientific symposium for animal, poultry and fish nutrition. Sakha, Egypt.

McNaughton, J. L. and J. W. Deaton (1981). Sunflowers: poultry application. Feed Mgt. 32(6),27.

Meng X, B.A. Slominski, C.M. Nyachoti, L.D. Campbell and W Guenter (2005). Degradation of cell wall polysaccharides by combinations of carbohydrase enzymes and their effect on nutrient utilization and broiler chicken. Poultry Science, 84: 37-47.

Michel, J. N. and M. L. Sunde (1985). Sunflower meals in pullet developer diet. Poult. Sci., 64: 669-674.

National Research Counsil (N.R.C.) (1994). Nutritional requirements of Poultry Ninth revised edition, National Academy Press Washington, D. C.

Osman. M, KH. Amber and Mona, A. Mahmoud (2004) response of broiler chicks performance to partial dietary inclusion of radish, rocket and parsley cakes . Egypt Poult. Sci. 24:25-264.

Panda, A.K., V. S. Rama Rao, M. V. L. N. Raju, S. S. Gajula and S. K. Bhanja (2007). Performance of broiler chickens fed low non phytate phosphorus diets supplemented with microbial phytase. J. Poult. Sci., 44:25-264.

Patterson, J.A. and K. M. Burkholder (2003). Application of prebiotics and probiotics in poultry production. Poult. Sci., 82:627-631.

Piray, A. H., H. Kermanshahi, A. M. Tahmasbi and J. Bahrampour (2007). Effects of cecal and aspergillus meal prebiotic (Fermacto) on growth performance and organ weights of broiler chickens. Int. J. Poult. Sci. 6:340-344

Rad. F. H. and K. Keshavarz (1976). Evaluation of the nutritional value of sunflower meal and possibility of substitution of sunflower meal by soybean meal in poultry diets. Poult. Sci., 55: 1757-1765.

Rebolé, A. M. L. Rodriíguez, C. Alzueta, L. T. Ortiz and J. Treviño (1999). A short note on effect of enzyme supplement on the nutritive value of broiler chick diets containing maize, soybean meal and full-fat sunflower seed. Anim. Feed Sci. and Tech. 78:153-158. 
Retiman S and S. Frankel (1957). Calorimetric method for the determination of blood, aminotransferase enzymatic activities. American J. of Clinical Pathology, 28: 56- 63.

Saleh FH, A. Ohtsuk, T. Tanak and K. Hayashi (2003). Effect of enzymes of microbial organs on in vitro digestibilities of dry matter, and crude protein of maize. J. of Poult. Sci., 40: 274-281.

SAS Institute (1990). SAS ${ }^{\circledR}$ User's Guide: Statistics. Version $6^{\text {th }}$ ed., SAS Institute Inc., NC. USA.

Selle, P.H., V. Ravindran, W.L. Bryden and T. Scott (2006). Influence of dietary phytate and exogenous phytase on amino acid digestibility in poultry: A review. J. of Poult. Sci., 43:89-103.

Sendroy, J. Jr. (1944). Determination of Calcium in plasma. J. Biological Chemistry, 152: 539.

Senkoylu, N. and N. Dale (1999) Sunflower meal in poultry diets: a review. World's Poult. Sci. J., 55:153-174.

Soliman A. Z., I. Hassan, S. Abou El-Wafa and A. G. Abdellah (1996). Utilization of High fiber sunflower meal with/without commercial enzymes or stabilized rumen extract in broiler diets. Egypt. Poult. Sci., 16:51-67.

Sun, X., A. A McElroy, K. E. Webb, Jr., A. E. Sefton and C. Novak (2005). Broiler performance and intestinal alterations when fed drug-free diets. Poult. Sci., 84:1294-1302.

Suresh, B.V., V. R. Reddy and A. R. Reddy (2000). Effect of dietary dilution with sunflower seed hulls on the performance of broilers. Archiv Fur Geflugelkunde, 64 (4): 162-166.

Tsvetanov, I. M., D.Tamova, N. Duneva and D. Chotinski (1984). Study on the use of sunflower meal in mixed feeds for broiler chickens 1 Characteristics of the product. Zhivotnov'dni-Nauki., 25: 37-41.

Volovinskaia, V. P. and B.Y. Kelman (1962). Modification of the water holding capacity method of meat F.D. industry, 11: 80 Moscow.

Waldroup, P. W., C. M. Hillard and R. J. Michell (1970). Sunflower meal as a protein supplement for broilers diets. Feedstuffs, 42(43), 41.

Watson D. (1960). Determination of cholesterol in blood. Clinical Chemist Acta, 5: 637.

Yonemochi, C., H. Fujisaki and H. Takagi (2003). Effects of amino acid, enzyme mixture and phytase added to low protein and low phosphorus diet on performance and excretion of nitrogen and phosphorus in broilers. Journal of Poultry Science, 40: 114-120.

Zanella, I., N. K. Sakomura, F. G. Silversides, A. Fiqueirdo and M. Pack (1999). Effect of enzyme supplementation of broiler diets based on corn and soybeans. Poultry Science 78:561-568.

Zatari, I. M. and J. L. Sell (1990). Sunflower meal as a compound of fatsupplemented diets for broiler chickens. Poultry Sic., 69: 1503-1507.

Zeweil, H.S. (1996). Enzyme supplements to diets of growing Japanese quails. Egypt. Poult. Sci. J., 16: 535-557. 
Aggoor, F. A. M. et al.

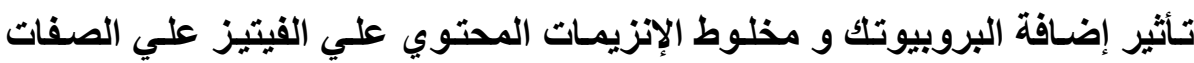

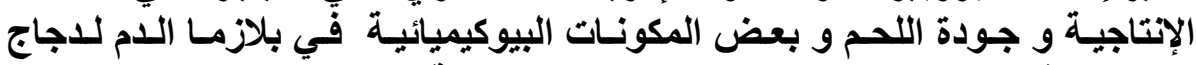

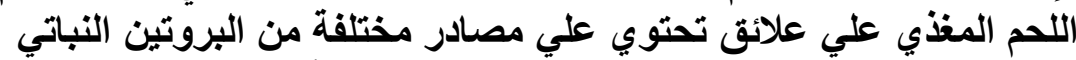

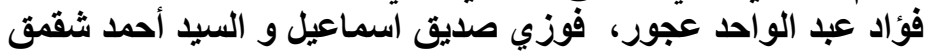

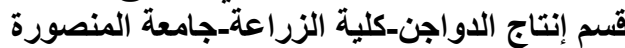

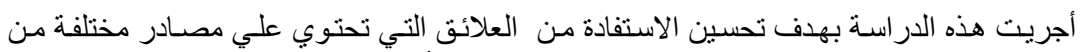

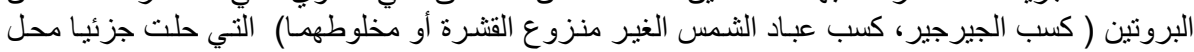

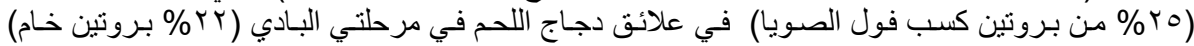

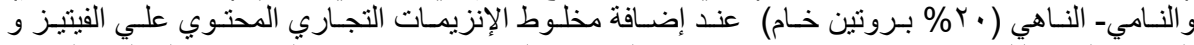

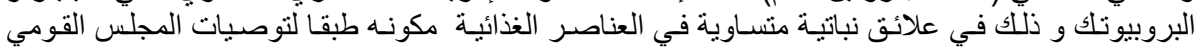

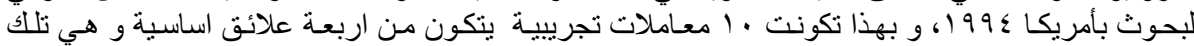

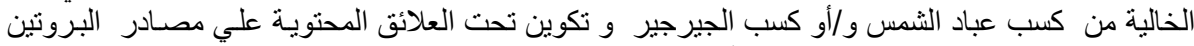

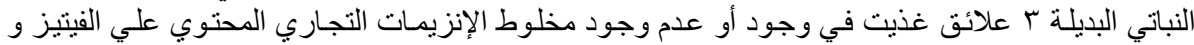

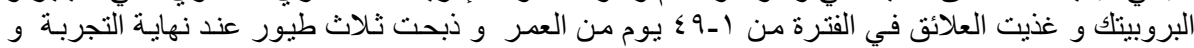

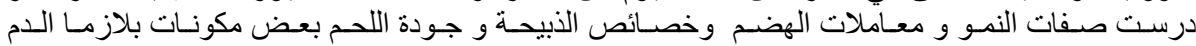
البيوكيميائية و الجدوى الاقتصادية والظهرت البرت النتائج آلاتي:-

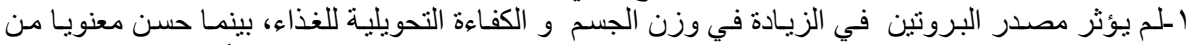

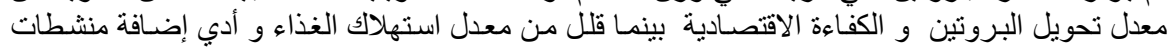

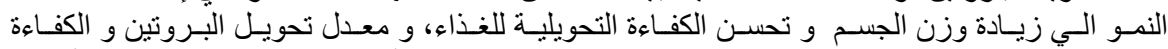

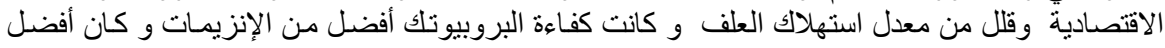

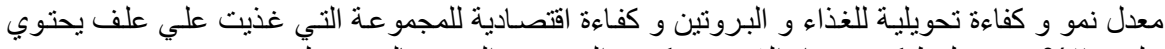

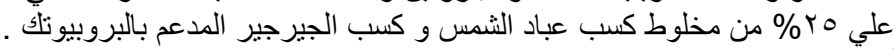

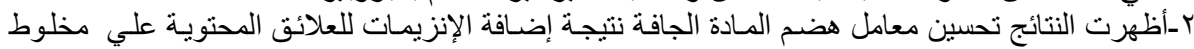

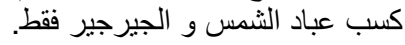

r-الم تؤثر المعاملات التجريبية و إضافة منشطات النمو علي النسبة المئوية للتصافي و نسبة الجزء الأمامي أو الخلفي للذبيحة.

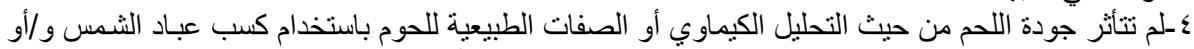

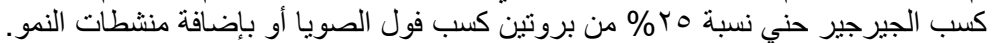

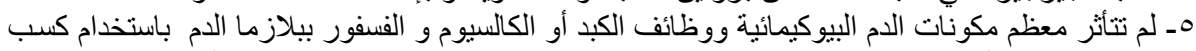

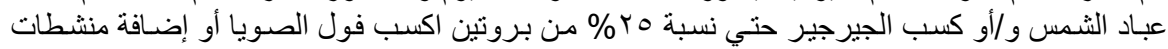
النمو.

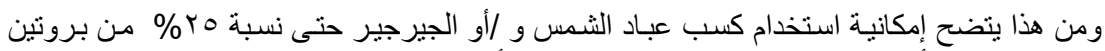

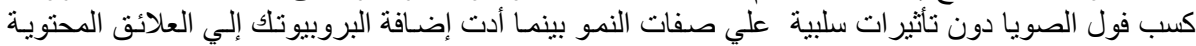

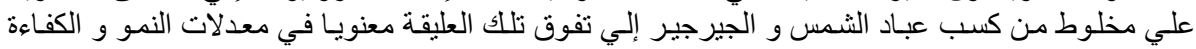

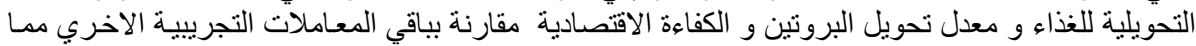

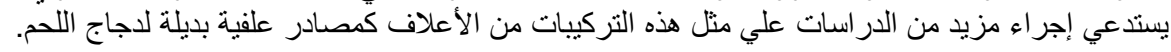


J. Agric. Sci. Mansoura Univ., 33 (4): 2501 - 2520, 2008

Aggoor, F. A. M. et al.

Aggoor, F. A. M. et al.

Aggoor, F. A. M. et al.

Aggoor, F. A. M. et al.

Aggoor, F. A. M. et al.

Aggoor, F. A. M. et al.

Aggoor, F. A. M. et al.

Aggoor, F. A. M. et al.

Aggoor, F. A. M. et al.

Aggoor, F. A. M. et al. 
Table (3): Effect of different protein sources and supplementation with multienzymes containing phytase and probiotics on growth ( $\mathrm{g} / \mathrm{bird} /$ period) and feed intake ( $\mathrm{g} / \mathrm{bird} /$ period) of broiler chicks.

\begin{tabular}{|c|c|c|c|c|c|c|c|c|c|c|c|c|}
\hline \multirow[b]{2}{*}{ Criteria } & \multirow[t]{2}{*}{ Control } & \multicolumn{3}{|c|}{ Sunflower meal } & \multicolumn{3}{|c|}{ Rocket meal } & \multicolumn{3}{|c|}{ Sunflower rocket mixture } & \multirow[t]{2}{*}{ SEM } & \multirow{2}{*}{$\begin{array}{c}P \\
\text { value }\end{array}$} \\
\hline & & - & Enzymes & Probiotics & - & Enzymes & Probiotics & - & Enzymes & Probiotics & & \\
\hline \multicolumn{13}{|c|}{ Growth of broilers during 1 to $49 \mathrm{~d}$ of age, g/chick } \\
\hline Body weight, $1 \mathrm{~d}$ of age $\mathrm{g}$ & 40.1 & 40.9 & 39.7 & 40.9 & 40.4 & 39.7 & 39.7 & 39.9 & 40.0 & 39.9 & 0.109 & NS \\
\hline BWG, 1-14 d of age & $290.8^{\dagger}$ & $291.6^{\dagger}$ & $329.0^{\text {cd }}$ & $341.9^{\mathrm{a}}$ & $290.3^{+}$ & $324.6^{d}$ & $336.4^{\mathrm{b}}$ & $298.1^{\mathrm{e}}$ & $330.9^{c}$ & $345.8^{a}$ & 1.824 & 0.001 \\
\hline BWG, $15-28 \mathrm{~d}$ of age & $830.2^{\mathrm{e}}$ & $834.0^{\mathrm{e}}$ & $893.9^{\text {cd }}$ & $928.3^{\mathrm{ab}}$ & $828.2^{\mathrm{e}}$ & $882.6^{d}$ & $912.5^{\mathrm{bc}}$ & $837.5^{\mathrm{e}}$ & $897.5^{\text {cd }}$ & $937.4^{\mathrm{a}}$ & 7.275 & 0.001 \\
\hline BWG, $29-49 \mathrm{~d}$ of age & $2212.6^{\mathrm{d}}$ & $2214.6^{d}$ & $2301.6^{\mathrm{bc}}$ & $2354.7^{\mathrm{ab}}$ & $2205.5^{d}$ & $2288.2^{\mathrm{c}}$ & $2332.5^{\text {abc }}$ & $2226.1^{d}$ & $2311.1^{\mathrm{bc}}$ & $2375.7^{\mathrm{a}}$ & 17.81 & 0.001 \\
\hline BWG, 1-49 d of age & $2172.5^{\mathrm{d}}$ & $2173.7^{d}$ & $2262.0^{\mathrm{bc}}$ & $2313.9^{\mathrm{ab}}$ & $2165.1^{\mathrm{d}}$ & $2248.5^{c}$ & $2292.9^{\mathrm{abc}}$ & $2186.2^{\mathrm{d}}$ & $2271.1^{\mathrm{bc}}$ & $2335.8^{\mathrm{a}}$ & 17.40 & 0.001 \\
\hline \multicolumn{13}{|c|}{ Feed intake of broilers during 1 to $49 \mathrm{~d}$ of age, $\mathbf{g} /$ chick/period } \\
\hline Feed intake, $1-14 \mathrm{~d}$ of age & $410.5^{\mathrm{a}}$ & $404.0^{\mathrm{bc}}$ & $399.5^{\text {def }}$ & $392.3^{\text {gh }}$ & $406.3^{b}$ & $400.5^{\text {cde }}$ & $396.5^{\text {efg }}$ & $401.9^{\text {cd }}$ & $395.6^{\mathrm{fg}}$ & $390.1^{1}$ & 1.444 & 0.0001 \\
\hline Feed intake, $15-28 \mathrm{~d}$ of age & $1114.8^{\mathrm{a}}$ & $1090.5^{b}$ & $1016.6^{\mathrm{e}}$ & $999.0^{9}$ & $1097.3^{\mathrm{b}}$ & $1034.0^{d}$ & $1009.1^{\mathrm{ef}}$ & $1079.5^{\mathrm{C}}$ & $1003.6^{\mathrm{fg}}$ & $990.4^{\mathrm{h}}$ & 2.856 & 0.0001 \\
\hline Feed intake, 29-49d of age & $3303.0^{\mathrm{a}}$ & $3248.4^{\text {bc }}$ & $3199.6^{\mathrm{de}}$ & $3178.6^{\text {ef }}$ & $3264.8^{\mathrm{b}}$ & $3227.1^{\text {cd }}$ & $3192.5^{\mathrm{ef}}$ & $3241.5^{\mathrm{bc}}$ & $3163.3^{t}$ & $3074.5^{9}$ & 10.89 & 0.0001 \\
\hline Feed intake, $1-49 \mathrm{~d}$ of age & $4828.1^{a}$ & $4742.4^{\mathrm{bc}}$ & $4615.8^{\mathrm{e}}$ & $4569.9^{f}$ & $4768.4^{\mathrm{b}}$ & $4661.3^{\mathrm{d}}$ & $4598.0^{\mathrm{ef}}$ & $4723.3^{c}$ & $4562.4^{\dagger}$ & $4454.6^{9}$ & 14.03 & 0.0001 \\
\hline
\end{tabular}

a,b,c, Means in the same row followed by different letters are significantly different at $(p \leq 0.05)$. NS = not significantly. 
Table (4): Effect of different protein sources and supplementation with multienzymes containing phytase and probiotics on feed conversion ratio (FCR; $\mathrm{g}$ feed/g gain), protein conversion ratio (PCR; $\mathrm{g}$ protein/ $\mathrm{g}$ gain), economic efficiency and apparent digestibility of nutrients of broiler chicks

\begin{tabular}{|c|c|c|c|c|c|c|c|c|c|c|c|c|}
\hline \multirow{2}{*}{ Criteria } & \multirow[t]{2}{*}{ Control } & \multicolumn{3}{|c|}{ Sunflower meal } & \multicolumn{3}{|c|}{ Rocket meal } & \multicolumn{3}{|c|}{ Sunflower with Rocket meal } & \multirow[t]{2}{*}{ SEM } & \multirow[t]{2}{*}{ P Value } \\
\hline & & - & Enzymes & robiotics & - & Enzymes & Probiotics & - & Enzymes & Probiotics & & \\
\hline \multicolumn{13}{|c|}{ Feed conversion ratio (FCR; $g$ feed/g gain), protein conversion ratio (PCR; g protein/g gain), economic efficiency } \\
\hline FCR,1-14 d of age & $1.687^{\mathrm{a}}$ & $1.661^{\mathrm{a}}$ & $1.427^{\mathrm{C}}$ & $1.347^{\mathrm{de}}$ & $1.671^{\mathrm{a}}$ & $1.425^{c}$ & $1.377^{\text {cde }}$ & $1.583^{\mathrm{b}}$ & $1.416^{\text {cd }}$ & $1.310^{\mathrm{e}}$ & 0.024 & 0.0001 \\
\hline FCR,15-28 d of age & $2.103^{a}$ & $2.044^{\mathrm{a}}$ & $1.829^{c}$ & $1.733^{\mathrm{de}}$ & $2.077^{\mathrm{a}}$ & $1.894^{\mathrm{b}}$ & $1.785^{\mathrm{cd}}$ & $2.044^{\mathrm{a}}$ & $1.788^{\text {cd }}$ & $1.702^{\mathrm{e}}$ & 0.020 & 0.0001 \\
\hline FCR, $29-49 \mathrm{~d}$ of age & $2.412^{\mathrm{a}}$ & $2.374^{\mathrm{ab}}$ & $2.295^{\text {cd }}$ & $2.252^{d}$ & $2.397^{a}$ & $2.325^{\mathrm{bc}}$ & $2.274^{\text {cd }}$ & $2.383^{a}$ & $2.261^{d}$ & $2.163^{e}$ & 0.019 & 0.0001 \\
\hline FCR, $1-49 \mathrm{~d}$ of age & $2.256^{a}$ & $2.211^{\mathrm{ab}}$ & $2.069^{\text {cd }}$ & $2.005^{f}$ & $2.214^{\mathrm{ab}}$ & $2.104^{c}$ & $2.037^{\mathrm{de}}$ & $2.190^{b}$ & $2.036^{\mathrm{de}}$ & $1.936^{\dagger}$ & 0.017 & 0.0001 \\
\hline PCR, 1-49 d of age & $0.486^{\mathrm{a}}$ & $0.478^{\mathrm{c}}$ & $0.446^{\dagger}$ & $0.432^{h}$ & $0.482^{b}$ & $0.454^{\mathrm{e}}$ & $0.439^{9}$ & $0.474^{d}$ & $0.440^{g}$ & $0.441^{i}$ & 0.00049 & 0.0001 \\
\hline $\begin{array}{l}\text { Economic efficiency, } \\
1-49 \mathrm{~d} \text { of age }\end{array}$ & $14.7^{i}$ & $16.4^{\mathrm{h}}$ & $21.9^{\mathrm{e}}$ & $25.1^{\mathrm{b}}$ & $16.4^{\mathrm{h}}$ & $20.8^{f}$ & $24.2^{\mathrm{c}}$ & $17.7^{9}$ & $23.3^{d}$ & $30.1^{\mathrm{a}}$ & 0.126 & 0.0001 \\
\hline \multicolumn{13}{|c|}{ Apparent digestibility of nutrients } \\
\hline Dry matter & $76.75^{\mathrm{c}}$ & $76.83^{c}$ & $79.46^{\mathrm{ab}}$ & $78.84^{\mathrm{abc}}$ & $77.09^{\mathrm{bc}}$ & $79.52^{\mathrm{ab}}$ & $79.29^{\mathrm{ab}}$ & $77.16^{\mathrm{bc}}$ & $80.37^{a}$ & $79.43^{\mathrm{ab}}$ & 0.548 & 0.0004 \\
\hline Crude protein & 76.89 & 77.18 & 79.79 & 79.61 & 77.21 & 79.24 & 80.13 & 76.92 & 80.44 & 79.99 & 1.159 & NS \\
\hline Crude fibre & 29.38 & 29.19 & 34.14 & 33.15 & 29.37 & 33.98 & 34.80 & 29.61 & 32.84 & 34.03 & 1.355 & 0.02 \\
\hline Crude ash & 29.63 & 28.18 & 30.89 & 29.80 & 29.86 & 30.16 & 31.06 & 27.86 & 31.38 & 30.57 & 1.174 & NS \\
\hline Ether extract & 77.13 & 77.15 & 79.55 & 79.73 & 78.42 & 80.40 & 79.17 & 77.39 & 79.21 & 79.52 & 1.125 & NS \\
\hline
\end{tabular}

${ }_{a, b, c}$ Means in the same row followed by different letters are significantly different at $(p \leq 0.05)$. NS = not significantly. 
Table (5). Effect of different protein sources and supplementation with multienzymes containing phytase and probiotics on carcass characteristics (\%), physical characteristics of meat and on chemical composition of fresh muscle of broiler chicks of broiler chicks

\begin{tabular}{|c|c|c|c|c|c|c|c|c|c|c|c|c|}
\hline \multirow[b]{2}{*}{ Criteria,\% } & \multirow[t]{2}{*}{ Control } & \multicolumn{3}{|c|}{ Sunflower meal } & \multicolumn{3}{|c|}{ Rocket meal } & \multicolumn{3}{|c|}{ Sunflower-rocket mixture } & \multirow[t]{2}{*}{ SEM } & \multirow[t]{2}{*}{ P value } \\
\hline & & - & Enzymes & Probiotics & - & Enzymes & Probiotics & - & Enzymes & Probiotics & & \\
\hline \multicolumn{13}{|c|}{ Carcass characteristics (\%) } \\
\hline Dressing & 62.8 & 63.7 & 63.9 & 63.9 & 62.5 & 63.0 & 63.7 & 63.9 & 64.2 & 64.5 & 0.990 & NS \\
\hline Inedible parts & 32.6 & 31.52 & 31.66 & 31.81 & 32.81 & 32.68 & 31.96 & 31.51 & 31.59 & 31.30 & 0.990 & NS \\
\hline \begin{tabular}{|l|} 
Front part \\
\end{tabular} & 32.8 & 35.5 & 34.3 & 34.0 & 33.0 & 33.4 & 34.3 & 34.1 & 34.6 & 34.7 & 0.877 & NS \\
\hline Hind part & 29.9 & 28.2 & 29.5 & 29.9 & 29.5 & 29.6 & 29.4 & 29.8 & 29.6 & 29.7 & 0.797 & NS \\
\hline Liver & $2.51^{\mathrm{a}}$ & $2.44^{\mathrm{ab}}$ & $2.35^{\mathrm{abcd}}$ & $2.09^{e}$ & $2.19^{\text {cde }}$ & $2.23^{\text {bcde }}$ & $2.18^{\mathrm{cde}}$ & $2.42^{\mathrm{abc}}$ & $2.22^{\text {bcde }}$ & $2.16^{\mathrm{de}}$ & 0.085 & 0.009 \\
\hline Gizzard & $1.41^{\mathrm{d}}$ & $1.52^{\mathrm{cd}}$ & $1.41^{\mathrm{d}}$ & $1.56^{\mathrm{c}}$ & $1.87^{\mathrm{a}}$ & $1.69^{\mathrm{b}}$ & $1.45^{\mathrm{cd}}$ & $1.47^{\text {cd }}$ & $1.38^{\mathrm{d}}$ & $1.44^{\text {cd }}$ & 0.046 & 0.0001 \\
\hline Heart & 0.687 & 0.709 & 0.688 & 0.642 & 0.631 & 0.613 & 0.703 & 0.697 & 0.612 & 0.596 & 0.042 & 0.05 \\
\hline Giblets & $4.60^{\mathrm{ab}}$ & $4.68^{\mathrm{a}}$ & $4.44^{\mathrm{abc}}$ & $4.29^{\mathrm{bc}}$ & $4.69^{\mathrm{a}}$ & $4.54^{\mathrm{ab}}$ & $4.34^{\mathrm{bc}}$ & $4.59^{\mathrm{ab}}$ & $4.21^{\mathrm{c}}$ & $4.20^{\mathrm{c}}$ & 0.096 & 0.007 \\
\hline \begin{tabular}{|l|} 
Spleen \\
\end{tabular} & $0.20^{\mathrm{bc}}$ & $0.25^{\mathrm{a}}$ & $0.23^{\mathrm{ab}}$ & $0.19^{c}$ & $0.20^{\mathrm{bc}}$ & $0.19^{\mathrm{bc}}$ & $0.22^{\mathrm{bc}}$ & $0.21^{\mathrm{bc}}$ & $0.21^{\mathrm{bc}}$ & $0.19^{\mathrm{c}}$ & 0.013 & 0.009 \\
\hline \multicolumn{13}{|c|}{ Physical characteristics of meat } \\
\hline Moisture, $\%$ & 75.08 & 74.76 & 74.51 & 74.62 & 74.75 & 74.60 & 74.22 & 74.28 & 74.51 & 74.18 & 0.241 & NS \\
\hline \begin{tabular}{|l|} 
Protein, $\%$ \\
\end{tabular} & 19.38 & 19.44 & 19.64 & 20.08 & 19.67 & 19.80 & 20.12 & 20.04 & 20.02 & 20.14 & 0.480 & NS \\
\hline Ether extract,\% & 4.11 & 4.36 & 4.28 & 3.99 & 4.05 & 4.19 & 4.25 & 4.29 & 4.16 & 4.25 & 0.374 & NS \\
\hline Ash & 1.49 & 1.40 & 1.46 & 1.45 & 1.43 & 1.34 & 1.35 & 1.31 & 1.25 & 1.38 & 0.062 & NS \\
\hline \multicolumn{13}{|c|}{ Chemical composition of fresh muscle } \\
\hline Color & 0.21 & 0.21 & 0.18 & 0.19 & 0.18 & 0.19 & 0.18 & 0.21 & 0.19 & 0.18 & 0.023 & NS \\
\hline $\mathrm{pH}$ & 6.38 & 6.47 & 6.38 & 6.42 & 6.33 & 6.59 & 6.52 & 6.61 & 6.31 & 6.45 & 0.121 & NS \\
\hline Tenderness & 2.74 & 2.79 & 2.81 & 2.81 & 2.77 & 2.77 & 2.85 & 2.85 & 2.87 & 2.84 & 0.087 & NS \\
\hline WHC & 5.64 & 5.78 & 5.62 & 5.72 & 5.66 & 5.71 & 5.70 & 5.67 & 5.67 & 5.74 & 0.095 & NS \\
\hline
\end{tabular}

NS = not significantly 
Table (6). Effect of different protein sources and supplementation with multienzymes containing phytase and probiotics on biochemical constituents of blood plasma of broiler chicks

\begin{tabular}{|c|c|c|c|c|c|c|c|c|c|c|c|c|}
\hline \multirow[b]{2}{*}{ Criteria } & \multirow[t]{2}{*}{ Control } & \multicolumn{3}{|c|}{ Sunflower meal } & \multicolumn{3}{|c|}{ Rocket meal } & \multicolumn{3}{|c|}{ Sunflower-rocket mixture } & \multirow[t]{2}{*}{ SEM } & \multirow{2}{*}{$\begin{array}{c}P \\
\text { value }\end{array}$} \\
\hline & & - & Enzymes & Probiotics & - & Enzymes & Probiotics & - & Enzymes & Probiotics & & \\
\hline Total protein, g/dl & 4.87 & 4.63 & 4.74 & 4.91 & 4.71 & 4.86 & 4.61 & 4.61 & 4.70 & 4.72 & 0.096 & NS \\
\hline Albumen, g/dl & $2.37^{\mathrm{a}}$ & $2.24^{\mathrm{ab}}$ & $2.29^{\mathrm{ab}}$ & $2.32^{\mathrm{ab}}$ & $2.35^{\mathrm{ab}}$ & $2.34^{\mathrm{ab}}$ & $2.25^{\mathrm{ab}}$ & $2.22^{\mathrm{b}}$ & $2.30^{\mathrm{ab}}$ & $2.26^{\mathrm{ab}}$ & 0.040 & 0.02 \\
\hline Globulin, g/dl & 2.50 & 2.39 & 2.45 & 2.59 & 2.36 & 2.52 & 2.36 & 2.39 & 2.40 & 2.46 & 0.065 & NS \\
\hline Alb/Glb ratio & 0.948 & 0.937 & 0.935 & 0.896 & 0.996 & 0.929 & 0.953 & 0.929 & 0.958 & 0.919 & 0.023 & NS \\
\hline Total lipids, mg/dl & 686 & 671 & 680 & 668 & 772 & 704 & 682 & 674 & 691 & 677 & 23.5 & NS \\
\hline Cholesterol, mg /dl & 171.8 & 171.3 & 164.5 & 182.8 & 171.0 & 164.1 & 178.5 & 161.4 & 169.4 & 174.7 & 5.98 & NS \\
\hline \begin{tabular}{|l} 
AST \\
\end{tabular} & 11.9 & 11.7 & 12.6 & 12.6 & 11.7 & 11.8 & 12.6 & 11.6 & 12.3 & 12.3 & 0.382 & NS \\
\hline$\overline{A L T}, \mathrm{U}$ & 6.89 & 6.73 & 6.21 & 7.04 & 6.51 & 6.24 & 6.63 & 6.27 & 6.71 & 6.42 & 0.223 & NS \\
\hline $\mathrm{Ca}, \mathrm{mg} / \mathrm{dl}$ & $11.69^{c}$ & $12.1^{\mathrm{bc}}$ & $12.7^{\mathrm{ab}}$ & $12.1^{\mathrm{bc}}$ & $12.0^{\mathrm{bc}}$ & $12.6^{\mathrm{ab}}$ & $12.3^{\mathrm{abc}}$ & $11.9^{\mathrm{bc}}$ & $13.1^{\mathrm{a}}$ & $12.2^{\mathrm{abc}}$ & 0.272 & 0.04 \\
\hline $\mathrm{iP}, \mathrm{mg} / \mathrm{dl}$ & 6.08 & 6.39 & 6.57 & 6.59 & 6.29 & 6.79 & 6.43 & 6.17 & 6.75 & 6.70 & 0.209 & NS \\
\hline
\end{tabular}

${ }_{a, b, c}$ Means in the same row followed by different letters are significantly different at $(p \leq 0.05)$. NS = not significantly 